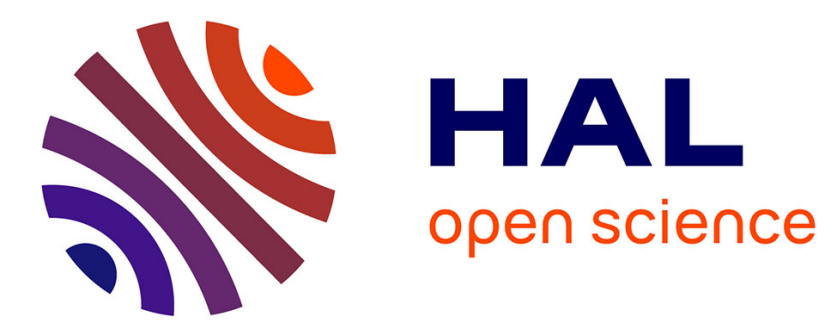

\title{
Fabrication of 3D printed antimicrobial polycaprolactone scaffolds for tissue engineering applications
}

Socrates Radhakrishnan, Sakthivel Nagarajan, Habib Belaid, Cynthia Farha, Igor Iatsunskyi, Emerson Coy, Laurence Soussan, Vincent Huon, Jonathan Barés, Catherine Teyssier, et al.

\section{To cite this version:}

Socrates Radhakrishnan, Sakthivel Nagarajan, Habib Belaid, Cynthia Farha, Igor Iatsunskyi, et al.. Fabrication of 3D printed antimicrobial polycaprolactone scaffolds for tissue engineering applications. Materials Science and Engineering: C, 2021, 118, pp.111525. 10.1016/j.msec.2020.111525 . hal03258024

\section{HAL Id: hal-03258024 https://hal.science/hal-03258024}

Submitted on 11 Jun 2021

HAL is a multi-disciplinary open access archive for the deposit and dissemination of scientific research documents, whether they are published or not. The documents may come from teaching and research institutions in France or abroad, or from public or private research centers.
L'archive ouverte pluridisciplinaire HAL, est destinée au dépôt et à la diffusion de documents scientifiques de niveau recherche, publiés ou non, émanant des établissements d'enseignement et de recherche français ou étrangers, des laboratoires publics ou privés. 
1 Fabrication of 3D printed antimicrobial polycaprolactone scaffolds for tissue engineering applications

3

4 Socrates Radhakrishnan ${ }^{1,2 \mu}$, Sakthivel Nagarajan ${ }^{2 \mu}$, Habib Belaid ${ }^{2,3}$, Cynthia Farha ${ }^{2}$, 5 Igor Iatsunskyi ${ }^{4}$, Emerson $\mathrm{Coy}^{4}$, Laurence Soussan ${ }^{2}$, Vincent Huon ${ }^{5}$, Jonathan Bares ${ }^{5}$, 6 Catherine Teyssier ${ }^{3}$, Sébastien Balme², Philippe Miele ${ }^{2,6}$, David Cornu ${ }^{2}$, Narayana $7 \quad$ Kalkura $^{1}$, Vincent Cavaillès ${ }^{3}$ and Mikhael Bechelany ${ }^{2 *}$

8

9 1. Crystal Growth Centre, Anna University, Chennai, India, 600025.

2. Institut Européen des Membranes, IEM UMR 5635, Univ Montpellier, CNRS, ENSCM,

11 Montpellier, France

12 3. IRCM, Institut de Recherche en Cancérologie de Montpellier, INSERM U1194, Université 13 Montpellier, Montpellier F-34298, France

14 4. NanoBioMedical Centre, Adam Mickiewicz University, 3 Wszechnicy Piastowskiej str., 15 61-614, Poznan, Poland

5. LMGC, Laboratoire de Mécanique et Génie Civil, Université Montpellier, CNRS, 17 Montpellier, France

18 6. Institut Universitaire de France (IUF), 1 rue Descartes, Paris F-73231, France

${ }^{\mu}$ Authors contributed equally

$21{ }^{*}$ Corresponding author: mikhael.bechelany@umontpellier.fr, Phone: +33467149167, Fax: $+33467149119$ 


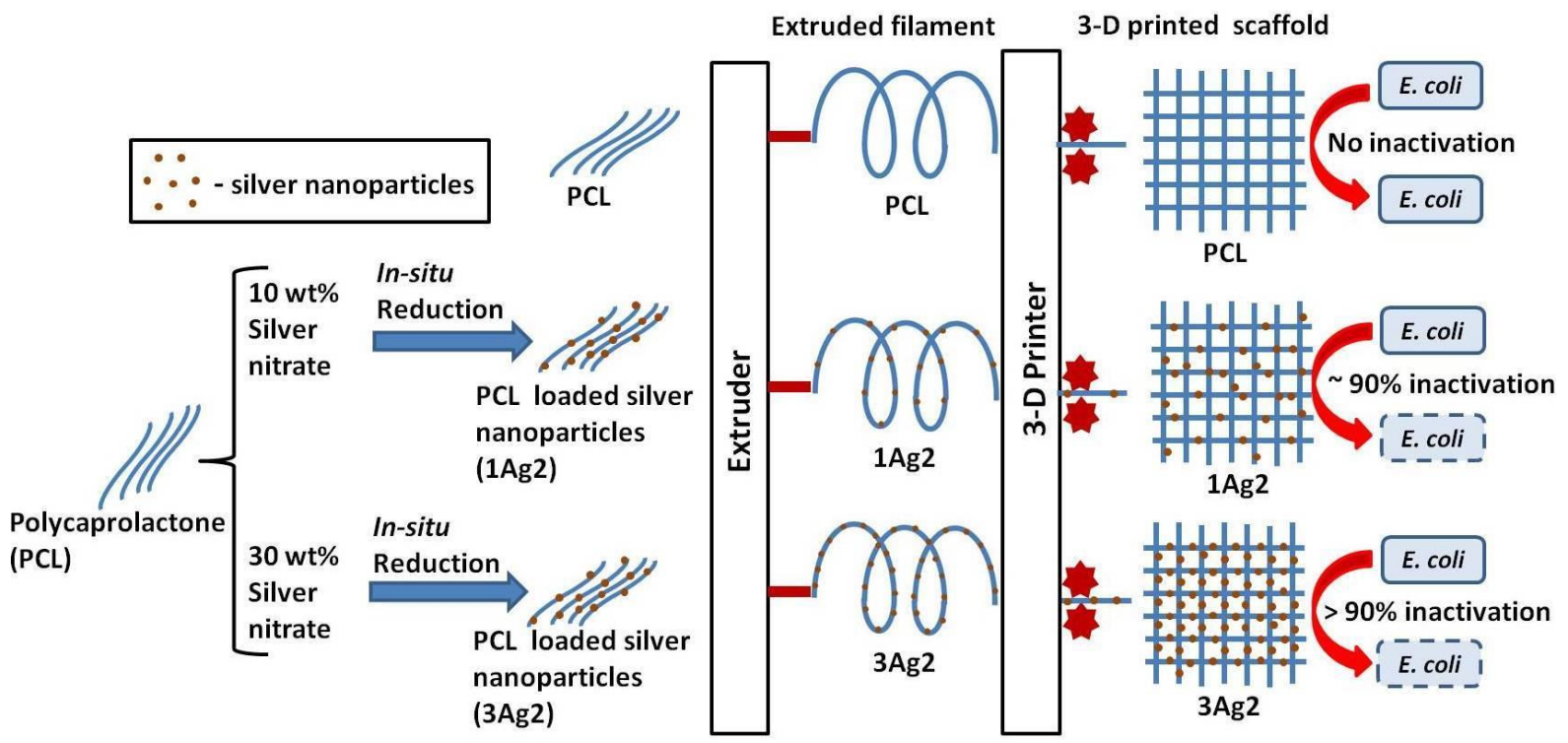

\begin{abstract}
Synthetic polymers are widely employed for bone tissue engineering due to their tunable physical properties and biocompatibility. Inherently, most of these polymers display poor antimicrobial properties. Infection at the site of implantation is a major cause for failure or delay in bone healing process and the development of antimicrobial polymers is highly desired. In this study, silver nanoparticles (AgNps) were synthesized in polycaprolactone
\end{abstract} (PCL) solution by in-situ reduction which was further extruded into PCL/AgNp filaments. Customized 3D structures were then fabricated using the PCL/AgNp filaments through 3D printing technique. As demonstrated by scanning electron microscopy, the 3D printed scaffolds exhibited interconnected porous structures which are crucial for cell infiltration. Furthermore, X-ray photoelectron spectroscopy analysis revealed the reduction of silver ion. Transmission electron microscopy along with energy-dispersive X-ray spectroscopy analysis revealed the formation of silver nanoparticles throughout the PCL matrix. In vitro enzymatic degradation studies showed that the PCL/AgNps scaffolds displayed 80\% degradation in 20 days. The scaffolds were cyto-compatible, as assessed by using MG63 cells and their antibacterial activity was demonstrated on Escherichia coli. Due to their interconnected porous structure, mechanical and antibacterial properties, these cyto-compatible multifunctional 3D printed PCL/AgNps scaffolds are highly suitable for bone tissue engineering. 


\section{Keywords:}

2 polycaprolactone, silver nanoparticles, nanocomposites, cytocompatibility, antimicrobial,

3 multifunctional properties

4

\section{Highlights:}

6 We report the development of antimicrobial polycaprolactone scaffold by 3D printing

7 The silver nanoparticles (AgNps) were obtained by in-situ reduction in PCL solution

$8 \quad$ AgNps reinforcement improved the stiffness of the 3D printed scaffolds

$93 \mathrm{D}$ printed scaffold exhibited multifunctional property

Fabricated 3D scaffold showed cytocompatibility and antimicrobial properties

\section{INTRODUCTION}

Fused deposition modelling (FDM) is one of the simple and cost effective techniques employed in $3 \mathrm{D}$ printing of polymers for bone tissue engineering ${ }^{1-2}$. Various thermoplastic polymers such as poly-e-capro-lactone (PCL) ${ }^{3}$, poly(L-lactic acid) (PLLA) ${ }^{4}$ and poly-vinylalcohol (PVA) ${ }^{5}$, have been used in 3D printing. Among them, PCL was widely used for the fabrication of bone scaffolds because of its FDA (Food and Drug Administration) approval, biocompatibility and biodegradation properties ${ }^{6}$. The low melting point $\left(60^{\circ} \mathrm{C}\right)$ of PCL is advantageous for 3D printing ${ }^{7}$. In addition, PCL exhibits good mechanical properties with high flexibility and great elongation at break $^{8}$, interesting for the preparation of scaffolds for craniofacial bone repair and cranial defects ${ }^{9}$. However, optimization of 3D printed PCL scaffolds by including other multifunctional properties such as antimicrobial activity and mechanical performance, without compromising their biocompatibility, is crucial to employ the scaffold for biomedical application.

About 2 to $5 \%$ of orthopaedic implants are complicated by infection ${ }^{10}$ and this can raise up to $30 \%$ in the case of open fractures ${ }^{11}$. Implant related infections are associated with significant morbidity and sometimes death. These complications lead to implant removal, surgical debridement of infected tissue and long-term antibiotic administration ${ }^{12-13}$. Loading of antibiotics or metallic component is an issue to impart antibacterial property to the scaffolds. For instance, Visscher et al. developed 3D printed PCL scaffolds containing macro- and micro-pores (obtained using porogen) and coated with antibiotic (®Cefazoline). These scaffolds were active against $S$. aureus ${ }^{14}$. This design is very potential, however the 
alarming levels of antibiotic resistance bacteria implies the necessity for developing potential alternate to this approach.

Silver, copper and zinc as metallic components are shown to exhibit antibacterial properties ${ }^{15}$. Among them, silver has been widely used in research and clinics as a broad spectrum antibacterial agent and apart from antibacterial application, silver nanoparticles-polymer composite has been used as catalytic agent ${ }^{16}$, super capacitors ${ }^{17}$, electromagnetic interference (EMI) shielding ${ }^{18}$, fuel cells ${ }^{19}$ etc., Mechanism of the antibacterial activity of silver nanoparticles (AgNps) is unclear. However, a recent investigation by Qing et al. provides possible explanations: (i) Anchoring of AgNps on bacterial membrane leads to membrane rupture and cellular content leakage that result in the bacterial cell death, (ii) Small size nanoparticles infiltrate the membrane and interact with the biomolecules which result in the dysfunction of bacterial cell, and (iii) AgNps are likely to catalyze $\mathrm{O}_{2}$ reduction into reactive oxygen species (ROS) whose accumulation leads to down regulation of antioxidant enzyme expression, DNA damages and apoptosis ${ }^{20}$.

Silver ions and its metallic nanoparticles can be directly incorporated into inorganic materials or mixed with synthetic and biopolymeric materials for the fabrication of antibacterial 3D printed structures ${ }^{21} 22$. For example, Muwaffak et al. developed 3D printed antimicrobial wound dressing material by incorporating ionic silver, copper and zinc oxide onto the PCL polymer. Silver and copper based PCL material displayed better bactericidal property than the zinc based material. However, this study is very limited and the influence of ionic silver on biocompatibility was not analyzed. ${ }^{23}$ AgNps were mixed with other synthetic polymers such as polyetheretherketone (PEEK) and 3D printed using FDM technique. The obtained scaffolds showed good antimicrobial properties ${ }^{24}$. Silver incorporation in tricalcium phosphate (as inorganic matrix) based 3D printed scaffolds facilitated differentiation of mesenchymal stem cells into osteoblasts ${ }^{25}$. PCL scaffolds were also synthesized with impregnated or surface coated silver nanoparticles in order to increase antibacterial activity ${ }^{26-}$ 28. The scaffolds fabricated through solvent casting and electrospinning technique display poor control over the architecture and the uncontrollable pore size in comparison to the $3 \mathrm{D}$ printing approach.

In this work, silver ions were in situ reduced into silver nanoparticles and encapsulated into the PCL matrix. The PCL composite (PCL/AgNps) was thermally extruded into PCL/AgNps filaments used for the fabrication of customized scaffolds by the FDM technique. After validation of in situ reduction, the enzymatic degradation of the scaffolds 
was elaborately analyzed. The antibacterial activity of the PCL and PCL/AgNps scaffolds was analyzed. Furthermore, scaffold cytocompatibility was evaluated using hFOB cells in order to assess their potential use for bone tissue engineering applications.

\section{Materials and Methods}

\section{Materials}

Polycaprolactone (PCL, Mw $50000 \mathrm{Da}$ ) pellets were obtained from polymorph (UK). N,N-Dimethylformamide (DMF; 99.8\%; CAS number 68-12-2; Sigma), Tetrahydrofuran (THF; 99\%; CAS number 109-99-9; Sigma), silver nitrate ( $\mathrm{AgNO}_{3}$; CAS number 7761-88-8, Sigma), Lipase cepacia (40.7 units/mg, CAS number 9001-62-1; Sigma), MEM $\alpha$ (Minimum Essential Medium $\alpha$ ) (A10490-01; Gibco), MTT (3-(4,5-Dimethylthiazol2-yl)-2,5-Diphenyltetrazolium Bromide) (98\%; CAS number 298- 93 -1), fetal bovine serum (FBS) (CVFSVF00-01; Eurobio), 1\% (V/V), penicillin/streptomycin (15140-122; Gibco), 0.05\% Trypsin-EDTA (25300-054; Gibco), Dimethyl sulfoxide (DMSO) (23486.297; BDH Prolab), ethanol (96\% vol; CAS number 64-17-5), phosphate buffered saline (PBS, P44717; Sigma), Lysogeny broth (LB) Miller culture medium (L3522; Sigma), microbiologic agar (A1296-1KG; Sigma), Bacteriopeptone (211677-500g; BD Biosciences), Yeast extract (9112001; Biokar diagnostics), Sodium Chloride (NaCl; 99\%; CAS number 7647-14-5; Sigma), Potassium dihydrogen phosphate $\left(\mathrm{KH}_{2} \mathrm{PO}_{4}\right.$; CAS number 7778-77-0), di-Sodium hydrogen phosphate dodecahydrate $\left(\mathrm{Na}_{2} \mathrm{HPO}_{4} \cdot 12 \mathrm{H}_{2} \mathrm{O}\right.$; CAS number: 10039-32-4 ; Sigma) and agar (CAS number 9002-18-0; Sigma) were obtained and used without further purification. hFOB osteoblastic cell line obtained from ATCC was used for cytocompatibility analysis. Non-pathogenic Gram-negative Escherichia coli bacterium (K12 DSM 423, from DSMZ, Germany) was used for the antibacterial study.

\section{Preparation of PCL/AgNps composite and extrusion of composite filaments}

PCL solution (10\% w/v) was prepared by dissolving it in solvent mixture (7:3 volume ratio of THF and DMF respectively) at $90^{\circ} \mathrm{C}$. Silver nitrate with 2 different percentages ( $1 \%$ and $3 \% \mathrm{w} / \mathrm{v}$ ) was added into the PCL solution and the temperature of the solution was maintained at $90^{\circ} \mathrm{C}$. Resultant solution was refluxed for 3 hours to facilitate the reduction of silver nitrate into silver nanoparticles. Brown polymer suspension was obtained which are cooled and precipitated using $300 \mathrm{~mL}$ of ethanol and dried at room temperature. PCL/AgNp composites prepared using $1 \%$ and $3 \%$ silver nitrate are denoted as $\mathrm{C} 1 \mathrm{Ag} 2$ and $\mathrm{C} 3 \mathrm{Ag} 2$. PCL, $\mathrm{C} 1 \mathrm{Ag} 2$ and $\mathrm{C} 3 \mathrm{Ag} 2$ were extruded into filament by Noztek pro extruder at $120^{\circ} \mathrm{C}$. 
2 Fabrication of 3D printed PCL/AgNp scaffold

PCL/AgNp scaffolds were fabricated using FDM technique. Scaffolds structure was customized using DesignSpark Mechanical® 2.0 software. The extruded filament was cast into 3D printed matrix by using FDM based 3D printer (PRUSA i3) and the settings are reported in the Table 1. Furthermore the scaffold made from the filaments of PCL, C1Ag2 and $\mathrm{C} 3 \mathrm{Ag} 2$ are denoted as PCL, $1 \mathrm{Ag} 2$ and $3 \mathrm{Ag} 2$.

Table 1 Printer settings employed for printing PCL and PCL/AgNp scaffolds

\begin{tabular}{|l|l|}
\hline Nozzle Diameter & $0.4 \mathrm{~mm}$ \\
\hline Extrusion width & $0.45 \mathrm{~mm}$ \\
\hline Layer height & $0.05 \mathrm{~mm}$ \\
\hline Fill density & $25 \%$ \\
\hline Fill pattern & Cubic \\
\hline Extruder temperature & $140^{\circ} \mathrm{C}$ \\
\hline Bed Temperature & $25^{\circ} \mathrm{C}$ \\
\hline Speed of print moves & $20-30 \mathrm{~mm} / \mathrm{s}$ \\
\hline
\end{tabular}

\section{Physical and chemical characterizations of the polymer and scaffolds}

Surface morphology of the scaffold was observed using HITACHI S4800 scanning electron microscopy system and the samples were sputter-coated for $30 \mathrm{~s}$ using platinum/palladium for SEM analysis. Here, Image J software was employed to calculate the mean filament diameter by taking average at 20 points and the pore size by taking average of 8 pores, which is denoted as mean \pm standard deviation. The Fourier transform infrared (FTIR) spectrum of the scaffold was recorded in the frequency range of $4000-600 \mathrm{~cm}^{-1}$ by NEXUS instrument in an attenuated total reflection (ATR) mode. X-Ray diffraction (XRD) analysis was performed by PANalytica Xpert powder XRD system using $\mathrm{Cu} \mathrm{K} \alpha$ radiation, $2 \theta$ range of $10-80^{\circ}$. X-ray photoelectron spectroscopy (XPS) analysis was performed using KRATOS- AXIS Ultra DLD model having monochromatic Al-K alpha source of $1486.6 \mathrm{eV}$ spectral resolution FWHM $0.45 \mathrm{eV}$. In situ synthesis of silver nanoparticles in the PCL polymer was characterized using TEM (JEOL ARM 200F) combined with an EDX Analyzer. 
1 For TEM analysis, polymer samples were cut into $90 \mathrm{~nm}$ thick slices after fixing it in Devcon

25 5 Minute Epoxy using ultra microtome and mounted over the $\mathrm{Cu}$ grid. Mechanical 3 properties of the PCL composites were assessed using a traction machine (MTS 1/ME) equipped with a $5 \mathrm{kN}$ force sensor. PCL composites were 3D printed as standard dog bones shapes to measure the mechanical properties and the analysis was performed in the strain rate of $0.01 \mathrm{~mm} \mathrm{~s}^{-1}$. Furthermore, Young's modulus and Poisson's ratio were calculated on minimum three assays as demonstrated elsewhere ${ }^{29-30}$.

\section{Enzymatic degradation of the PCL and PCL/AgNp scaffolds}

In vitro degradation of the scaffolds was carried out using lipase enzyme at concentration of 10 units $/ \mathrm{mL}$. The lipase solution was prepared from $0.01 \mathrm{M}$ phosphatebuffered saline (PBS) at $\mathrm{pH}$ 7.4. The samples were weighed and placed in a vial containing the $1 \mathrm{ml}$ lipase solution and incubated at $37^{\circ} \mathrm{C}$. Every 3 days, the enzyme solution was replenished with fresh lipase solution. After definite time, the samples were removed from the enzyme solution, washed, dried at $37^{\circ} \mathrm{C}$ and weighed. The percentage of degradation of the scaffold was calculated by measuring the ratio of the final weight of the sample to that of the initial weight (taken in the range of $9.0-15.0 \mathrm{mg}$ ) of the sample that is after and before the degradation.

\section{Cell viability assay}

hFOB osteoblastic cells were cultured using DMEM/F12 (Dulbecco's Modified Eagle Medium $\alpha$ ) (Gibco 10565018) conditioned media supplemented with (i) $10 \%$ (V/V) fetal bovine serum (FBS) (Eurobio CVFSVF00-01). Cells were cultured at $37^{\circ} \mathrm{C}$ in $5 \% \mathrm{CO}_{2}$ in a $10 \mathrm{~cm}$ diameter petri dish and trypsinized using 0.05\% Trypsin-EDTA (Gibco 25300-054). After sterilization with $70 \%(\mathrm{w} / \mathrm{v})$ ethanol for $30 \mathrm{mins}$, the printed scaffolds were dried at room temperature and then placed in contact with hFIB cells for 8 days. Cell viability was analyzed using MTT assay carried out by incubating $100 \mu \mathrm{L}$ of $0.5 \mathrm{mg} / \mathrm{mL}$ of MTT solution on the cells for $3 \mathrm{~h}$. Purple coloured formazan crystals were dissolved using $40 \mu \mathrm{L}$ of DMSO (BDH Prolab 23486.297) and the absorbance was recorded at $560 \mathrm{~nm}$ using Multiskan plate reader (thermos, USA).

\section{Antibacterial activity}

Antibacterial activity of the 3D PCL/AgNp scaffold was characterized by soft agar and liquid tests to study bacterial growth inhibition and bactericidal action respectively (the 
1 detailed protocols are given in the supportive information S1). The samples used for the antibacterial activity trials were sterilized by immersion in a water/ethanol $(3: 7 \mathrm{v} / \mathrm{v})$ solution for $1 \mathrm{~h}$ and washed afterwards for several times with sterile deionized water to remove the ethanol traces in the sample. Later the washed samples were sterilely dried at $30^{\circ} \mathrm{C}$ overnight and used for the antibacterial activity tests. Bacterial growth inhibition tests were carried out by putting the samples in contact with a nutritive soft agar inoculated with bacteria. Bactericidal action of the material was characterized by incubating the material in a suspension of resting bacteria (i.e., un-growing bacteria).

\section{RESULTS AND DISCUSSION}

PCL/AgNps composite was synthesized through in situ reduction -mechanism (equation 1 and 2) as described by Santos et al. ${ }^{31}$. Obtained PCL/AgNp was utilized for the fabrication of customized 3D printed structure (Figure 1). Physicochemical properties, biocompatibility as well as antimicrobial properties of the PCL and PCL/AgNps scaffolds were analyzed and discussed.

$\mathrm{HCONMe}_{2}+2 \mathrm{Ag}^{+}+\mathrm{H}_{2} \mathrm{O} \longrightarrow 2 \mathrm{Ag}^{0}+\mathrm{Me}_{2} \mathrm{NCOOH}+2 \mathrm{H}^{+}$

Santos et al. ${ }^{31}$. described that the carbamic acid undergoes decomposition at high temperature followed by evaporation.

$\mathrm{Me}_{2} \mathrm{NCOOH} \longrightarrow \mathrm{CO}_{2}+\mathrm{Me}_{2} \mathrm{NH}$

Figure 1. Photograph of the 3D printed scaffolds (scale bar denotes $1 \mathrm{~cm}$ )

\section{Physicochemical properties of the scaffolds}

Scanning electron microscopy SEM images of the 3D printed PCL and PCL/AgNps scaffolds are shown in the Figure 2. SEM micrographs revealed that the PCL and PCL/AgNps 3D scaffolds matrix displayed uniform porous structures with open and interconnected pores. Inter filament spacing resulting from the fusion of multiple layers of polymer filaments are denoted as pores as mentioned in the literature ${ }^{21,32}$. 3D structure and pore size of the 
1 scaffolds plays a crucial role in cell infiltration. Murphy et al. demonstrated that the scaffolds

2 having 80 to $190 \mu \mathrm{m}$ pore size display cell aggregation and poor cells infiltration. Scaffolds

3 of $300 \mu \mathrm{m}$ pores size possess improved cells infiltration and the cells were observed at the

4 center of the scaffolds without cell aggregation. These results prove that the pores sizes above

$5300 \mu \mathrm{m}$ is crucial in the scaffolds design ${ }^{33}$. Scaffolds obtained in our study displayed pore

6 size larger than $300 \mu \mathrm{m}$ (Table 2), this dimension being suitable for osteoblast cell

7 infiltration. The diameter of 3D printed filaments is also shown in Table 2. SEM micrographs

8 of $1 \mathrm{Ag} 2$ and $3 \mathrm{Ag} 2$ revealed homogeneous filament diameters which is crucial in order to

9 obtain scaffolds with uniform architectures. High magnification SEM micrograph reveals wrinkly surface morphology for PCL and almost smooth and uniform surface for 1Ag2 and 3Ag2 (Figure 1). Here, AgNps act as the inorganic filler leading to the increased stiffness which is evident from the increased Young's modulus.
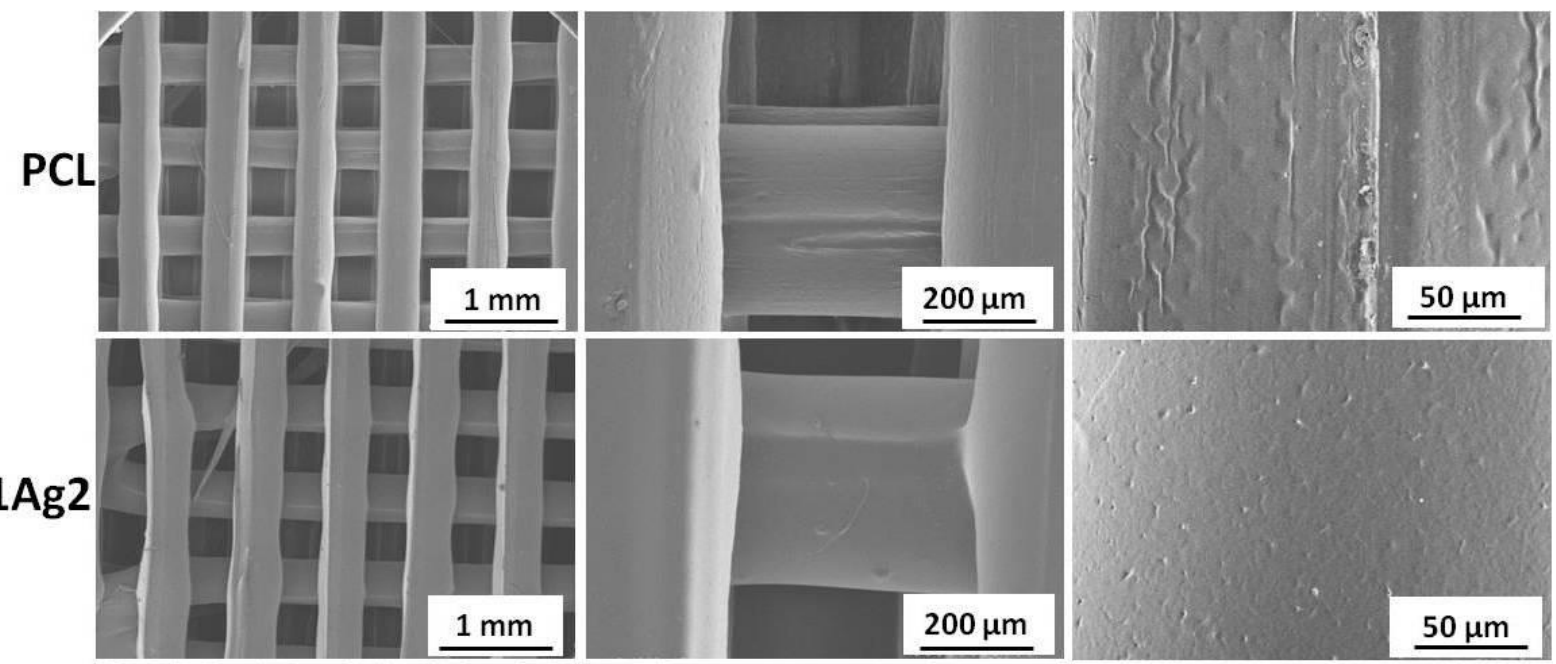

3Ag2
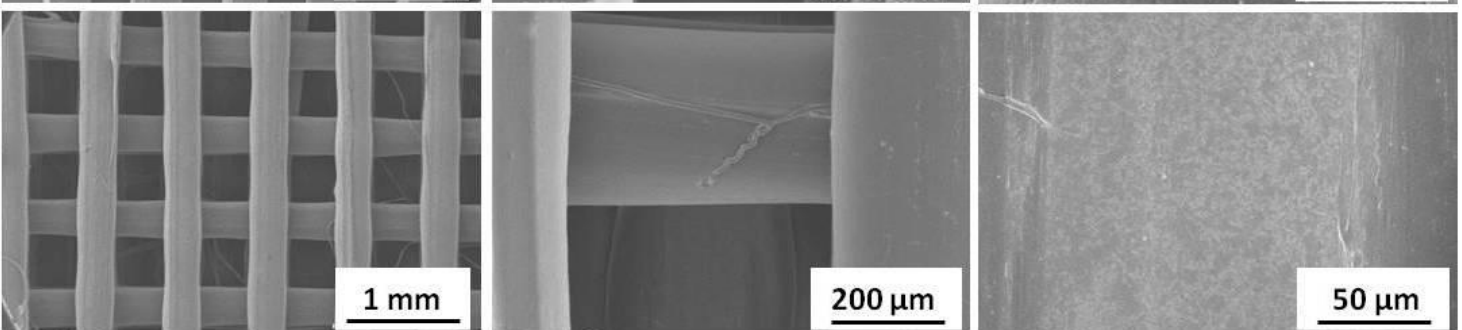

Figure 2. SEM analysis of 3D printed scaffolds

Table 2. Dimensions of the printed 3D scaffold

\begin{tabular}{|l|l|l|l|}
\hline & PCL & $1 \mathrm{Ag} 2$ & $3 \mathrm{Ag} 2$ \\
\hline Pore size $(\mu \mathrm{m})$ & $430.0 \pm 29.8$ & $379.6 \pm 21.2$ & $431.7 \pm 24.6$ \\
\hline Filament diameter $(\mu \mathrm{m})$ & $349.1 \pm 21.6$ & $406.4 \pm 23.3$ & $333.9 \pm 12.0$ \\
\hline
\end{tabular}


FTIR analysis was used to identify the functional groups of the 3D printed PCL and

3 PCL/AgNps scaffolds and the interaction between PCL and AgNps. The FTIR spectra are 4 shown in Figure 3(A). The intense peak at $1721 \mathrm{~cm}^{-1}$ is assigned to the stretching mode of 5 carbonyl groups of PCL. The peaks at $2865 \mathrm{~cm}^{-1}$ and $2944 \mathrm{~cm}^{-1}$ correspond to the symmetric 6 and asymmetric stretching of $\mathrm{CH}_{2}$ groups in PCL polymer backbone. The peaks at $1238 \mathrm{~cm}^{-1}$ 7 and $1161 \mathrm{~cm}^{-1}$ are due to symmetric and asymmetric stretching of C-O-C groups of PCL. The 8 peaks at $1187 \mathrm{~cm}^{-1}$ and $1292 \mathrm{~cm}^{-1}$ are related to O-C-O stretching, and C-O and C-C stretching modes respectively ${ }^{34}$. PCL display polar functional groups $>\mathrm{C}=\mathrm{O}$ and $-\mathrm{C}-\mathrm{O}-\mathrm{C}-$ and their position of the corresponding peaks remains unaffected during the in situ reduction of silver ions into silver nanoparticles using $\mathrm{DMF}^{35}$.
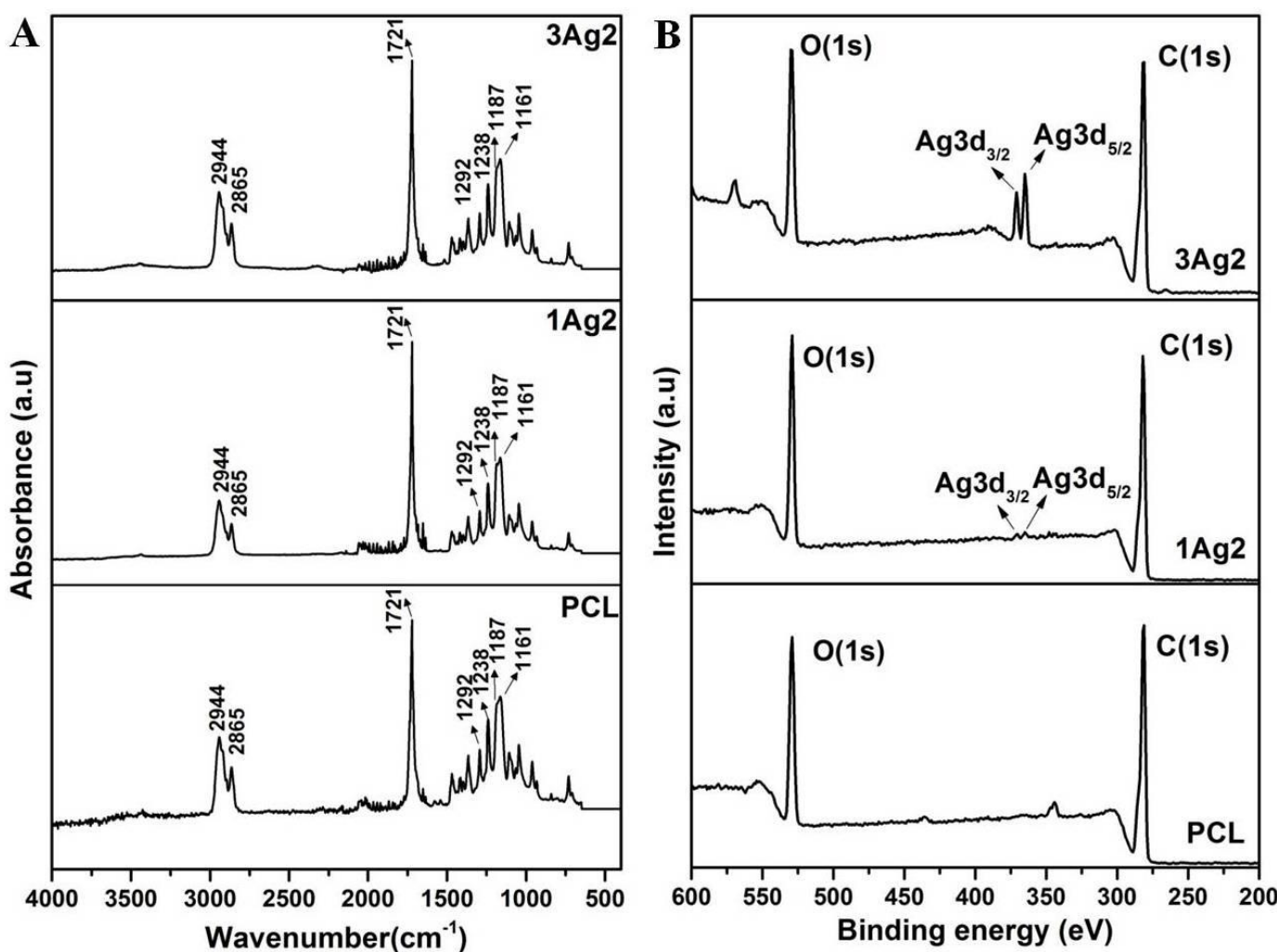

Figure 3. (A) FTIR and (B) XPS spectra of 3D printed scaffolds

X-ray photoelectron spectroscopy (XPS) analysis was used to confirm the formation of silver nanoparticles in the PCL/AgNp composite. The 3D printed scaffolds were scanned in the range of 200 to $600 \mathrm{eV}$.(figure 3(B)) The XPS spectra showed the peaks of C 1S, and O $1 \mathrm{~S}$ which correspond to the PCL. The Ag $3 d$ peaks $\left(3 d_{3 / 2}, 3 d_{5 / 2}\right)$ are observed in the $1 \mathrm{Ag} 2$ and 
$13 \mathrm{Ag} 2$ samples. They confirm the presence of silver in these scaffolds. The peak separation

2 (energy difference of $\mathrm{Ag} 3 \mathrm{~d}$ peaks) of $\mathrm{Ag} 3 \mathrm{~d}_{3 / 2}, 3 \mathrm{~d}_{5 / 2}$ is $6 \mathrm{eV}$ which corresponds to the reduced

3 silver. These results show that the reduction of ionic silver into metallic silver is effectively

4 achieved using $\mathrm{DMF}^{31,36-38}$. Furthermore, silver concentration in $1 \mathrm{Ag} 2$ and $3 \mathrm{Ag} 2$ was

5 quantified using AAS as 1.34 and $15.22 \mathrm{mg} / \mathrm{g}$ of the 3D printed matrix respectively.

6 X-ray diffraction (XRD) was used to determine the crystalline structures of the AgNps/PCL

7 3D printed scaffolds (Figure 4(A)) The XRD diffractogram of the scaffolds PCL, 1Ag2 and

$83 \mathrm{Ag} 2$ are characterized by diffraction peaks at $2 \Theta=21.2^{\circ}, 21.7^{\circ}$ and $23.5^{\circ}$ which correspond

9 to (110), (111) and (200) crystal planes of PCL respectively ${ }^{39}$. The diffraction peak observed

10 at $38.8^{\circ}$ (Figure $4(\mathrm{~B})$ ) in $1 \mathrm{Ag} 2$ and $3 \mathrm{Ag} 2$ diffractograms corresponds to the (111) plane of

11 Ag. It confirms the presence of silver in $1 \mathrm{Ag} 2$ and $3 \mathrm{Ag} 2$ scaffolds.
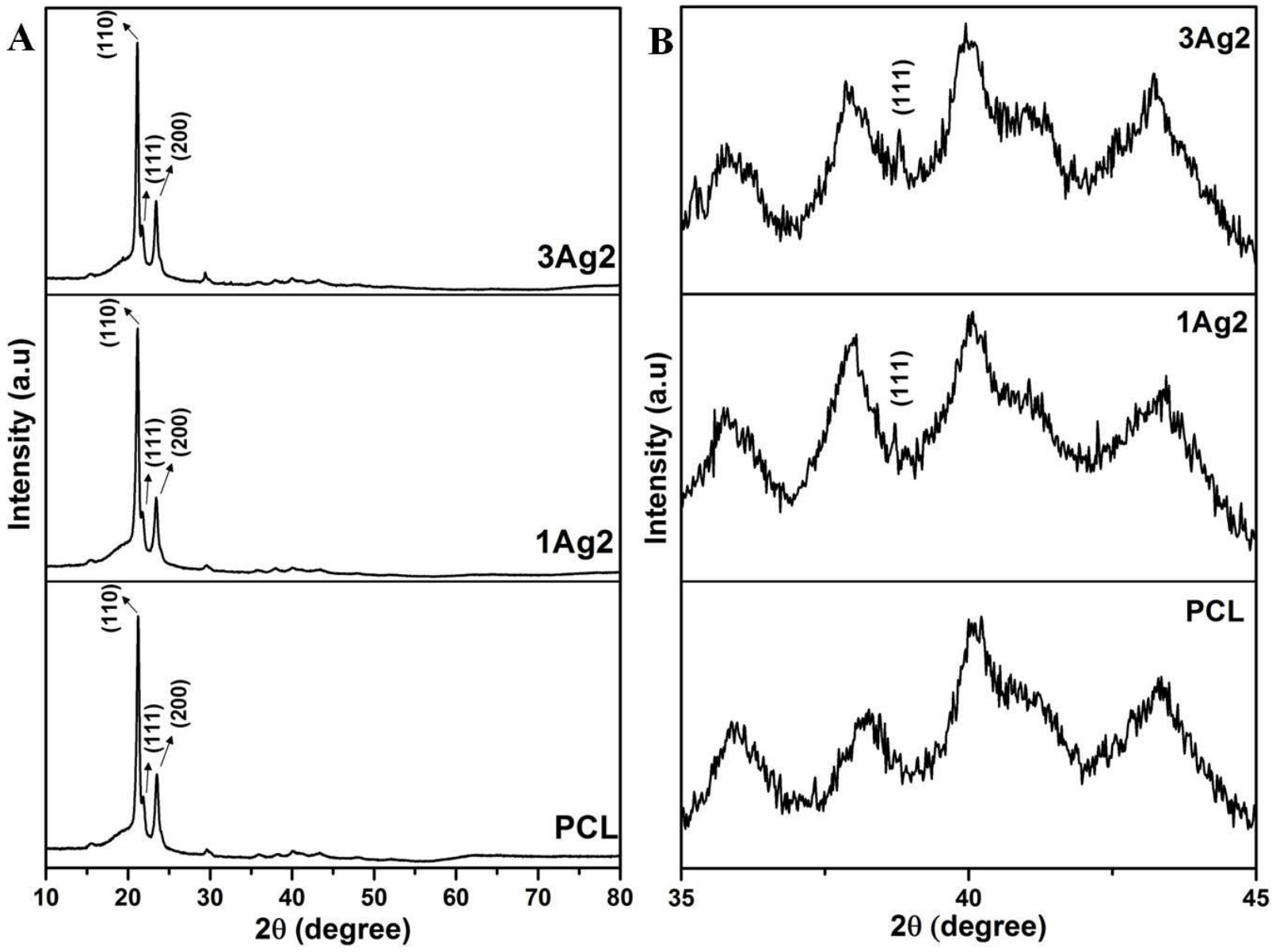

Figure 4. XRD analysis of 3D printed scaffolds, (A) Whole diffractogram and (B) diffractogram of specific regions. 
In situ synthesis and distribution of the silver nanoparticles in the 3D printed PCL matrix was analyzed using transmission electron microscopy (TEM) along with EDX analysis (Figure 5(a-d)). TEM bright field micrographs of 3Ag2 clearly reveal the distribution of silver nanoparticles as spots throughout the PCL matrix (Figure 5(a, b)). The sizes distribution is in the range of 20 to $150 \mathrm{~nm}$ (Figure 5c) exemplifying wide dispersity of the synthesized silver nanoparticles. Furthermore, EDX analysis confirms the distribution of silver nanoparticles in the PCL polymer matrix. Therefore, the presence of the silver nanoparticles in the PCL matrix is probably responsible of the antibacterial activity as it will be demonstrated later.
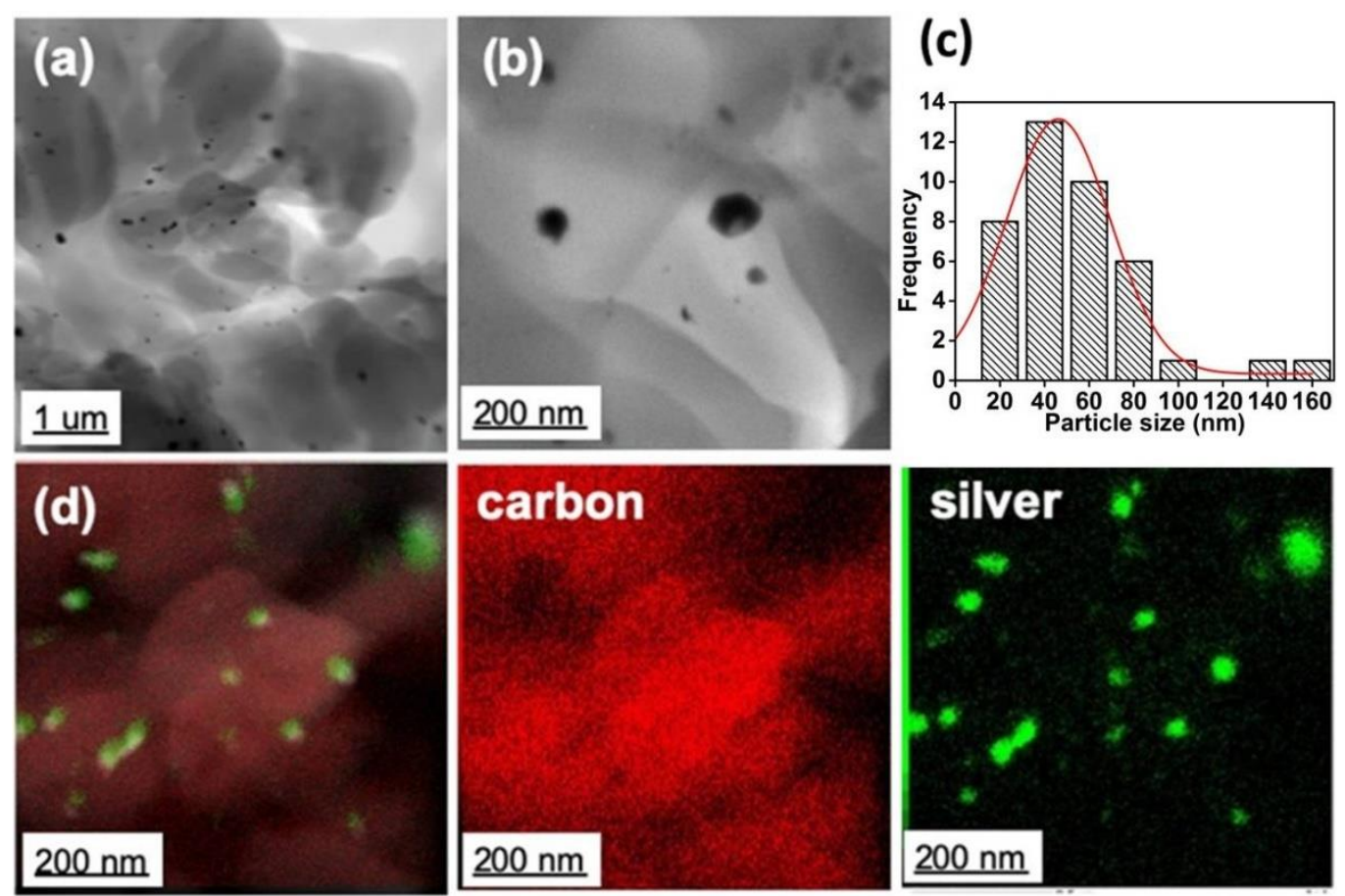

Figure 5. (a)-(b) TEM images of 3Ag2 sample, (c) Ag particle size distribution and (d) EDX elemental mapping of $3 \mathrm{Ag} 2$ scaffolds; Silver (green) and Carbon(red).

Materials used for implant tissue engineering applications should possess mechanical properties suitable for the targeted tissue. Therefore, the mechanical properties of 3D printed pristine PCL and PCL/Ag were characterized using tensile test analysis (Figure 6). Firstly the Poisson's ratio for PCL was 0.38 and remains constant with the addition of silver nanoparticles. Young's modulus of PCL was found to be $0.35 \mathrm{GPa}$ which is in good agreement with the literature ${ }^{40}$. For PCL/Ag (1Ag2 and 3Ag2), the Young's modulus increases from 0.35 (PCL) to $1 \mathrm{GPa}(3 \mathrm{Ag} 2)$. Generally, the fillers restrict the mobility of polymer matrix and enhance the rigidity of the scaffolds ${ }^{41-42}$. In this study, silver nanoparticles are also acting as fillers which decrease the elastic behavior of PCL and 
1 improve its rigidity. Furthermore, increasing the silver concentration enhanced the Young's 2 modulus of the PCL/AgNP (1Ag1 and 3Ag2) composite scaffolds. Here, the values of 3 Young's modulus of the composites are between that of the cancellous bone (0.05-0.1 GPa) 4 and cortical bone (3-30 GPa) ${ }^{43}$. These results also support the employment of the composite 5 scaffolds for bone tissue engineering application.

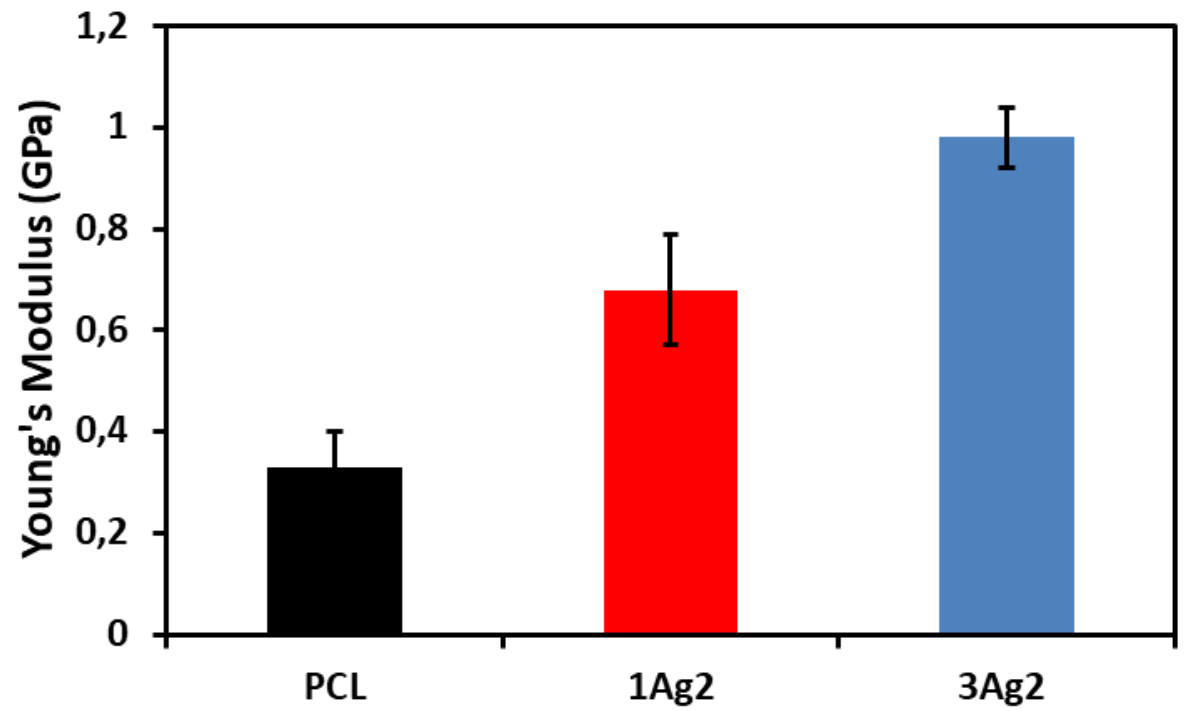

Figure 6. Mechanical property, Young's modulus of 3D printed scaffolds.

\section{Enzymatic degradation test}

In vitro enzymatic degradation analysis was used to evaluate stability of the $3 \mathrm{D}$ printed PCL/AgNp scaffolds. Lipase was employed because PCL possesses an ester bond prone to hydrolytic degradation by lipase. For this assay, the pre-weighed PCL, 1Ag2 and 3Ag2 scaffolds were immersed in the lipase solution and their degradation was recorded (Figure 6). PCL, 1Ag2 and 3Ag2 scaffolds display <10\% degradation in 24 hours. The degradation of PCL scaffolds gradually increased to reach $82 \%$ degradation after 20 days. Generally, polymer undergoes surface degradation due to the direct contact of enzyme ${ }^{44}$. Scaffolds (PCL, 1Ag2 and 3Ag2) fabricated in this study are interconnected porous scaffolds which display large surface area to interact with enzymes that can facilitate the degradation. Neumann et al. 3D printed PCL and PCL/CaCO 3 scaffolds and analyzed the degradation of the scaffolds using $15 \mathrm{U} / \mathrm{mL}$ lipase. Our material exhibits a degradation profile similar to the degradation profile obtained by Neumann et al. in which PCL undergoes $80 \%$ degradation in 20 days $^{45}$. 


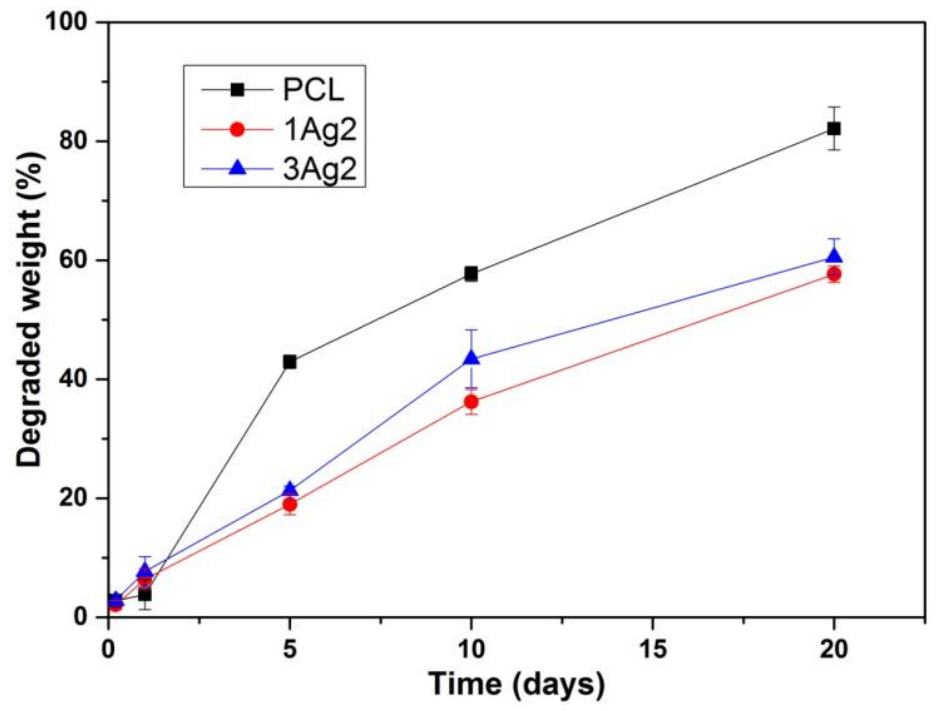

Figure 7. Enzymatic degradation of 3D printed scaffolds

\section{Biocompatibility analysis}

Biocompatibility of the PCL, 1Ag2 and 3Ag2 scaffolds was assessed using hFOB cells which are a good in vitro model of bone cells (REF?). Cells grown on the tissue culture plate without scaffold served as tissue culture plate control (TCP). Biocompatibility of the 3D printed scaffolds was calculated by comparing cell viability of the 3D printed scaffolds with the TCP control. Cell viability data shown in Figure 8 were presented as mean \pm standard deviation (S.D) and statistical analysis done using Student's t test indicating "ns" not significant and $* \mathrm{p}<0.05$ with sample size, $\mathrm{n}=8$.

Afer 8 days of culture, PCL scaffolds did not show any toxicity to the cells which evidences that the solvents employed for the preparation of 3D scaffolds are effectively removed. $1 \mathrm{Ag} 2$ allowed a better proliferation of the cells compared than PCL while $3 \mathrm{Ag} 2$ display a decrease in cell viability. Cell viability of $3 \mathrm{Ag} 2$ observed is likely due to the high concentration of silver loaded in the PCL matrix. However, cell viability was found to be greater than $80 \%$ after 8 days which fits within the acceptable limits as set by ISO109935:2009. Despite their toxicity, silver and silver based formulation are utilized for commercial biomedical products such as PolyMem ${ }^{\circledR}$ Silver, Aquacel ${ }^{\circledR}$ Ag, Acticoat ${ }^{\mathrm{TM}}$, Urgotul ${ }^{\circledR S S D}$, Contreet ${ }^{\circledR}$. Indeed, silver can be eliminated through urinary excretion in humans ${ }^{47}$. Nevertheless, 3D printed PCL/AgNps display low cytotoxicity, suggesting that they could be suitable for tissue engineering application. 


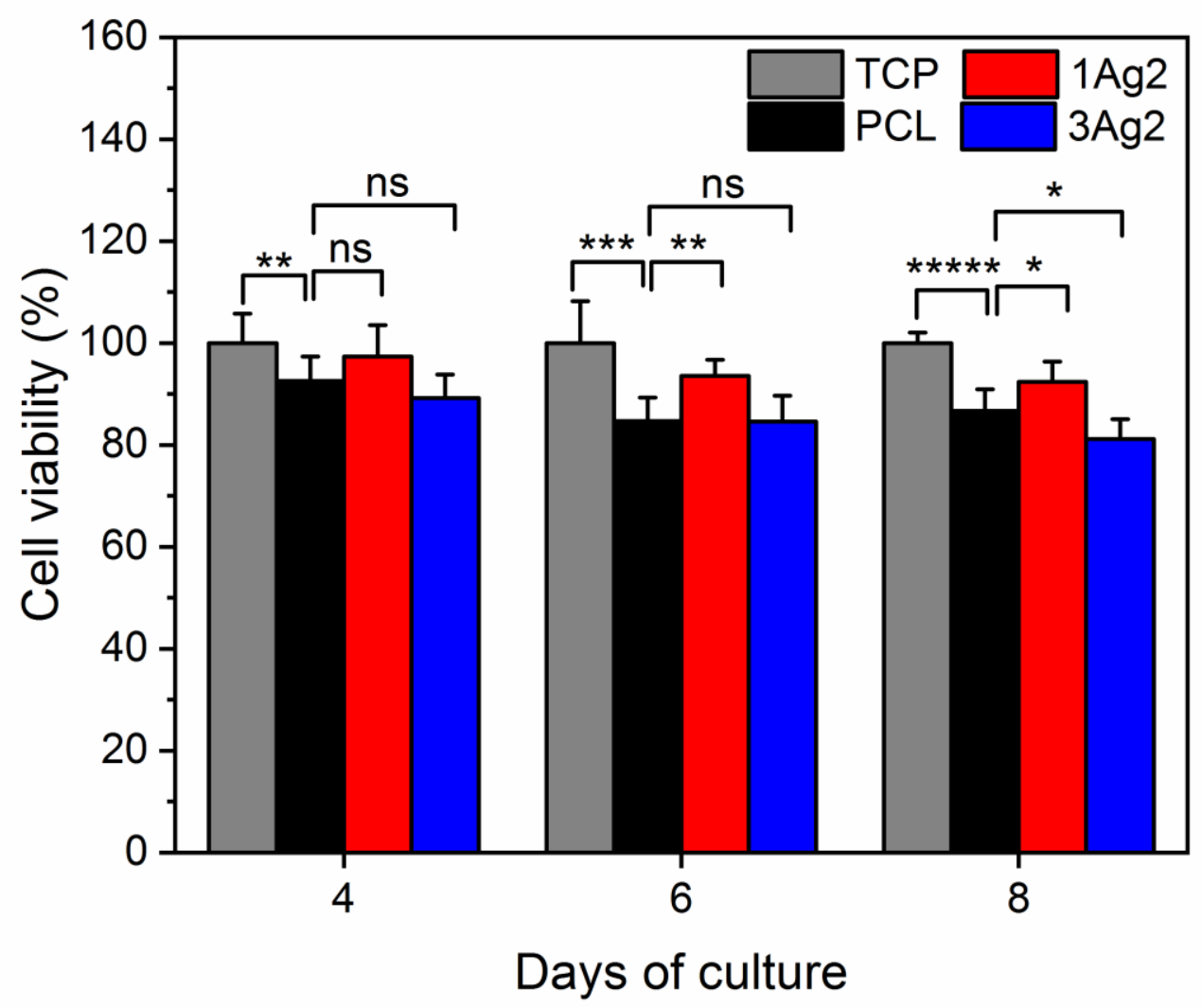

1

3

4

5

6

7

8

9

10

Figure 8. hFOB osteoblastic cell viability after 8 day of culture on of 3D printed scaffolds.

(ns $=$ not significant, $* \mathrm{p}<0.05, * * \mathrm{p}<0.005$ and $* * * * * \mathrm{p}<0.000005)$

\section{Bacterial growth inhibition test}

Antibacterial activity of the materials was first characterized by growth inhibition tests. Bacterial growth inhibition test was performed to assess the ability of the material to prevent the implanted site from the formation of bacterial biofilm in presence of nutrients since it could lead to bacterial infection. Figure 9 presents the results obtained for the inhibition tests performed at $24 \mathrm{~h}$. 


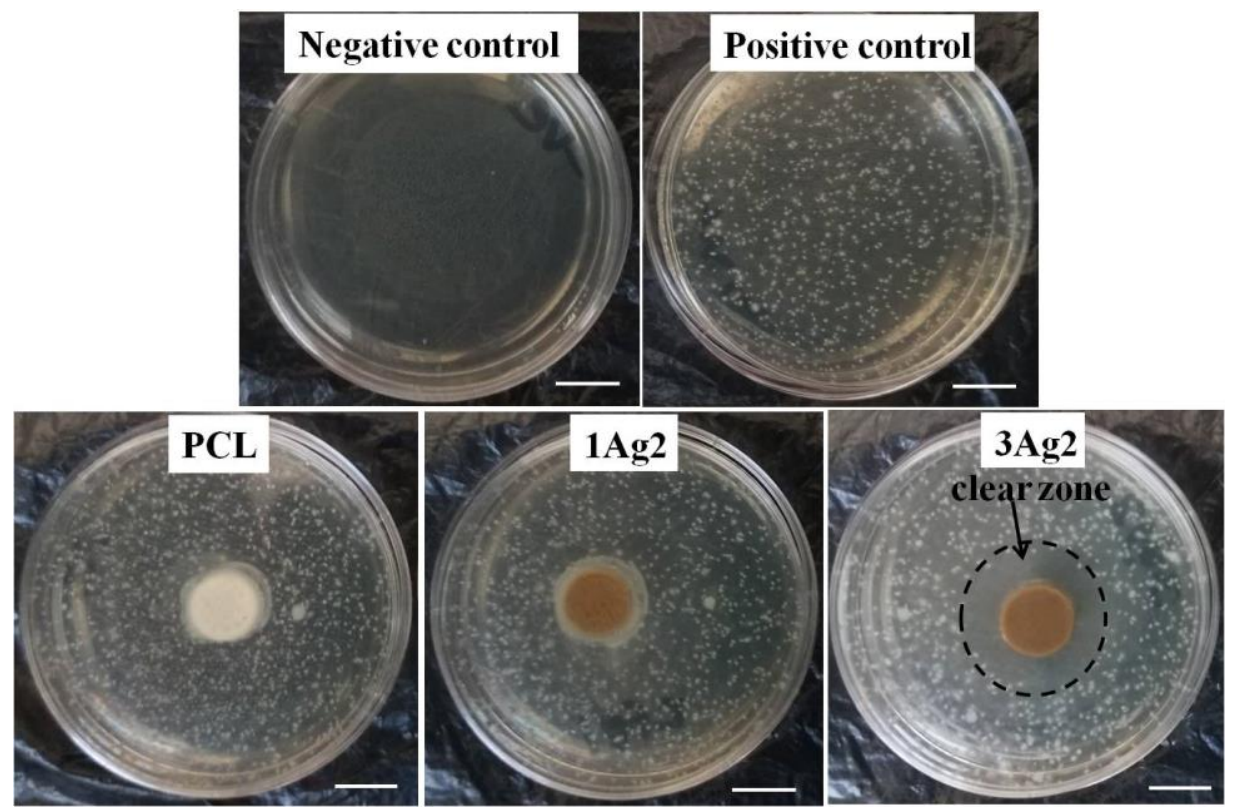

2 Figure 9. Soft agar plates inoculated with E. coli cells and incubated with 3D printed scaffolds in their center for $24 \mathrm{~h}$ (Scale bar denotes $1 \mathrm{~cm}$ )

Negative control plates (i.e. without bacteria and material) show clear nutritive soft agar plates while positive control plates (i.e., with bacteria and without material) show a uniform distribution of bacterial colonies within the soft agar (Fig. 9). With 3Ag2 material, a clear inhibition zone of mean diameter $20.4 \pm 1.7 \mathrm{~mm}$ is observed whereas no clear zone is observed for PCL and 1Ag2 (Fig. 9) for which biofilms are evidenced on the material surfaces. The presence of an inhibition zone around the $3 \mathrm{Ag} 2$ material evidences an antibacterial activity based on the diffusion of biocidal agents through the soft agar. These biocidal agents might be silver (most likely $\mathrm{Ag} 0$ rather than $\mathrm{Ag}^{+}$according to XPS analysis) and/or ROS. This antibacterial activity does not exclude a bactericidal surface action by the AgNP present on the material, but the soft agar test does not allow to conclude on that.

\section{Bactericidal activity}

Bactericidal tests were done to assess the ability of the material to remove bacteria that has already grown on the material implantation zone. Bactericidal activity was assessed by liquid tests in which the material $(90 \pm 10 \mathrm{mg})$ was immersed in a bacterial suspension (10 $\mathrm{mL}$ ) at about $10^{2} \mathrm{CFU} / \mathrm{mL}$. Table 3 shows the bacterial concentrations (CFU/mL) and the associated log-removal values, where the log-removal is defined as the logarithm $(\log )$ ratio of the bacterial concentration $C$ measured after respective contact time relative to the initial bacterial concentration $C_{0}$. A log-removal value of $-\log \left(C_{0}\right)$ was attributed to the particular 
case of total removal of the cultivable bacteria. A log-removal value higher than 1 is related to a significant bactericidal activity, i.e., to a reduction in bacterial concentration higher than $90 \%$. Table 3 reports also the total silver concentration measured by AAS in the liquid after $24 \mathrm{~h}$ contact.

Table 3. Log-removals and concentrations of released silver obtained in bactericidal tests against an $E$. coli suspension; the initial bacterial concentration $\mathrm{C}_{0}$ was $175 \pm 50 \mathrm{CFU} / \mathrm{mL}$

\begin{tabular}{|l|l|l|l|l|l|}
\hline & \multicolumn{2}{|l|}{ After 6 h contact } & \multicolumn{2}{l|}{ After 24 h contact } \\
\hline Test & $\begin{array}{l}\text { Bacterial } \\
\text { concentration } \\
(\mathbf{C F U} / \mathbf{m L})\end{array}$ & $\begin{array}{l}\mathbf{L o g} \\
\text { removal } \\
(-)\end{array}$ & $\begin{array}{l}\text { Bacterial } \\
\text { concentration } \\
(\mathbf{C F U} / \mathbf{m L})\end{array}$ & $\begin{array}{l}\mathbf{L o g} \\
\text { removal } \\
(-)\end{array}$ & $\begin{array}{l}\text { Total silver } \\
\text { concentration } \\
(\mathbf{m g} / \mathbf{L})\end{array}$ \\
\hline CPositive control & $\mathbf{1 7 5} \pm \mathbf{5 0}$ & $\mathbf{0}$ & $\mathbf{1 7 5} \pm \mathbf{5 0}$ & $\mathbf{0}$ & - \\
\hline CPCL & $115 \pm 5$ & 0.2 & $135 \pm \mathbf{0}$ & 0.1 & - \\
\hline C $_{1 \mathrm{Ag} 2}$ & $145 \pm 40$ & 0.1 & $10 \pm 10$ & 1.2 & 0.06 \\
\hline C $_{\text {3Ag2 }}$ & $5 \pm 5$ & 1.5 & $0 \pm \mathbf{0}$ & 2.2 & 0.44 \\
\hline
\end{tabular}
time respectively (Table 3). As PCL was not reported to have any antibacterial activity, the log-removal observed is probably due to bacteria adsorption on the PCL. It is thus likely that such an adsorption also occurred for the silver materials. After $6 \mathrm{~h}$ only, $3 \mathrm{Ag} 2$ material shows a significant decrease of the bacterial concentration corresponding to a log-removal value of 1.5 (Table 3), which is close to the maximal log-removal value reachable (i.e. $-\log C_{0}=2.2$ ). Hereafter $24 \mathrm{~h}, 1 \mathrm{Ag} 2$ depicted a marked decrease of bacterial concentration leading to a logremoval value of 1.2 and $3 \mathrm{Ag} 2$ material managed to inactivate all the bacteria initially present. This result clearly evidences the bactericidal activity of the $1 \mathrm{Ag} 2$ and $3 \mathrm{Ag} 2$ materials due to the presence of AgNPs in the material.

AAS measurements reveal that small silver concentrations were released in the suspension after $24 \mathrm{~h}$ (Table 3), which corresponds to silver mass lost by the material of $6.0 \times 10^{-4} \mathrm{mg}$ for $1 \mathrm{Ag} 2$ and $4.4 \times 10^{-3}$ for $3 \mathrm{Ag} 2$ respectively. Since the initial silver content of the materials were $0.13 \% \mathrm{w} / \mathrm{w}$ for $1 \mathrm{Ag} 2$ and $1.5 \% \mathrm{w} / \mathrm{w}$ for $3 \mathrm{Ag} 2$, and the samples weight were $90 \pm 10 \mathrm{mg}$, it means that the mass of silver incorporated in PCL were $0.12 \mathrm{mg}$ for 
$1 \quad 1 \mathrm{Ag} 2$ and $1.35 \mathrm{mg}$ for $3 \mathrm{Ag} 2$ respectively. After $24 \mathrm{~h}$ of reaction, $1 \mathrm{Ag} 2$ consequently lost 0.05

$2 \%$ of its silver whereas $3 \mathrm{Ag} 2$ lost $0.3 \%$. This result demonstrates the good chemical stability

3 of both PCL/AgNps materials in presence of bacteria. In the case of $1 \mathrm{Ag} 2$, a bactericidal action of the surfaces is mainly evidenced because the silver released in the bacterial suspension is very small $(<0.1 \mathrm{mg} / \mathrm{L})$. For $3 \mathrm{Ag} 2$, a coupled action of both the AgNps surface and the silver desorbed can be suspected. The need for a longer contact time ( $24 \mathrm{~h} \mathrm{vs} 6 \mathrm{~h}$ ) to observe a bactericidal activity of $1 \mathrm{Ag} 2$ might consequently be due to a lower content of silver nanoparticles on the material surface contacting the bacteria. These results are consistent with the fact that the antibacterial activity depends on the quantity of silver nanoparticles which is acting as the antibacterial agent ${ }^{48}$.

\section{Conclusion}

PCL/AgNps polymer composite was achieved through in situ reduction of silver ions using DMF as a reducing agent as well as solvent. Synthesized PCL/AgNps composites were extruded into self-standing filaments further utilized for the fabrication of customized 3D porous structures using 3D printing technique. XRD, XPS, TEM and EDAX analysis confirmed the presence of silver nanoparticles within the 3D printed matrix. SEM analysis of the scaffolds shows that the $3 \mathrm{D}$ printed scaffolds displayed interconnected porous structures wrinkly surface on PCL and uniform smooth surface on 1Ag2 and 3Ag2 scaffolds. Here the presence of silver nanoparticles in the PCL scaffold improved its stiffness (Young's modulus) and enzymatic stability. Soft agar test showed that 3Ag2 scaffold exhibited an inhibition zone where E. coli growth is prevented around the scaffold due presumably to ROS and silver nanoparticles diffusion from PCL scaffold to soft agar. Besides, a biocidal surface action was evidenced for both $1 \mathrm{Ag} 2$ and $3 \mathrm{Ag} 2$. Furthermore, we show that the 3D printed scaffolds exhibit cytocompatibility. Altogether, our study shows that the scaffolds developed could be utilized for the fabrication of antimicrobial scaffolds for bone tissue engineering application.

\section{Acknowledgements}

The authors would like to thank for the financial support from Indo-French Centre for the promotion of advanced research-Cefipra (Project 5608-1). This study was supported as well by the University of Montpellier (MUSE “3DTraitCancer” project). I.I and E.C. acknowledge the partial financial support by project H2020-MSCA-RISE-2017, 'Novel 1D photonic metal oxide nanostructures for early stage cancer detection' (Project number: 778157). I.I. also acknowledges the support of dr. Łucja Przysiecka in TEM sample preparation. 


\section{References:}

4 1. Gibson, I.; Rosen, D.; Stucker, B., The Impact of Low-Cost AM Systems. In Additive 5 Manufacturing Technologies: 3D Printing, Rapid Prototyping, and Direct Digital Manufacturing, 6 Gibson, I.; Rosen, D.; Stucker, B., Eds. Springer New York: New York, NY, 2015, pp 293-301.

7 2. Belaid, H.; Nagarajan, S.; Barou, C.; Huon, V.; Bares, J.; Balme, S.; Miele, P.; Cornu, D.; 8 Cavaillès, V.; Teyssier, C.; Bechelany, M., Boron Nitride Based Nanobiocomposites: Design by 3D 9 Printing for Bone Tissue Engineering. ACS Applied Bio Materials 2020.

$103 . \quad T e m p l e$, J. P.; Hutton, D. L.; Hung, B. P.; Huri, P. Y.; Cook, C. A.; Kondragunta, R.; Jia, X.; Grayson, W. L., Engineering anatomically shaped vascularized bone grafts with hASCs and 3D-printed PCL scaffolds. Journal of Biomedical Materials Research Part A 2014, 102 (12), 4317-4325.

4. Belaid, H.; Nagarajan, S.; Teyssier, C.; Barou, C.; Barés, J.; Balme, S.; Garay, H.; Huon, V.; Cornu, D.; Cavaillès, V.; Bechelany, M., Development of new biocompatible 3D printed graphene oxide-based scaffolds. Materials Science and Engineering: C 2020, 110, 110595.

5. He, H.-Y.; Zhang, J.-Y.; Mi, X.; Hu, Y.; Gu, X.-Y., Rapid prototyping for tissue-engineered bone scaffold by 3D printing and biocompatibility study. Int J Clin Exp Med 2015, 8 (7), 11777-11785.

6. Sun, H.; Mei, L.; Song, C.; Cui, X.; Wang, P., The in vivo degradation, absorption and excretion of PCL-based implant. Biomaterials 2006, 27 (9), 1735-1740.

7. Más Estellés, J.; Vidaurre, A.; Meseguer Dueñas, J. M.; Castilla Cortázar, I., Physical characterization of polycaprolactone scaffolds. Journal of Materials Science: Materials in Medicine 2008, 19 (1), 189-195.

8. Matzinos, P.; Tserki, V.; Gianikouris, C.; Pavlidou, E.; Panayiotou, C., Processing and characterization of LDPE/starch/PCL blends. European Polymer Journal 2002, 38 (9), 1713-1720.

9. Osteogenic Induction of Human Bone Marrow-Derived Mesenchymal Progenitor Cells in Novel Synthetic Polymer-Hydrogel Matrices. Tissue Engineering 2003, 9 (4), 689-702.

10. Darouiche, R. O., Treatment of Infections Associated with Surgical Implants. New England Journal of Medicine 2004, 350 (14), 1422-1429.

11. Trampuz, A.; Widmer, A. F., Infections associated with orthopedic implants. Current Opinion in Infectious Diseases 2006, 19 (4), 349-356.

12. Lazzarini, L.; Mader, J. T.; Calhoun, J. H., Osteomyelitis in Long Bones. JBJS 2004, 86 (10), 2305-2318.

13. Lew, D. P.; Waldvogel, F. A., Osteomyelitis. The Lancet 2004, 364 (9431), 369-379.

14. Visscher, L. E.; Dang, H. P.; Knackstedt, M. A.; Hutmacher, D. W.; Tran, P. A., 3D printed Polycaprolactone scaffolds with dual macro-microporosity for applications in local delivery of antibiotics. Materials Science and Engineering: C 2018, 87, 78-89.

15. Morones-Ramirez, J. R.; Winkler, J. A.; Spina, C. S.; Collins, J. J., Silver enhances antibiotic activity against gram-negative bacteria. Sci Transl Med 2013, 5 (190), 190ra81-190ra81.

16. Lu, S.; Yu, J.; Cheng, Y.; Wang, Q.; Barras, A.; Xu, W.; Szunerits, S.; Cornu, D.; Boukherroub, R., Preparation of silver nanoparticles/polydopamine functionalized polyacrylonitrile fiber paper and its catalytic activity for the reduction 4-nitrophenol. Applied Surface Science 2017, 411, 163-169.

17. Patil, D. S.; Pawar, S. A.; Patil, P. S.; Kim, J. H.; Shin, J. C., Silver Nanoparticles Incorporated PEDOT-PSS Electrodes for Electrochemical Supercapacitor. Journal of Nanoscience and Nanotechnology 2016, 16 (10), 10625-10629.

18. Lee, T.-W.; Lee, S.-E.; Jeong, Y. G., Highly Effective Electromagnetic Interference Shielding Materials based on Silver Nanowire/Cellulose Papers. ACS Applied Materials \& Interfaces 2016, 8 (20), 13123-13132.

19. Choudhury, A., Polyaniline/silver nanocomposites: Dielectric properties and ethanol vapour sensitivity. Sensors and Actuators B: Chemical 2009, 138 (1), 318-325. 
20. Qing, Y. a.; Cheng, L.; Li, R.; Liu, G.; Zhang, Y.; Tang, X.; Wang, J.; Liu, H.; Qin, Y., Potential antibacterial mechanism of silver nanoparticles and the optimization of orthopedic implants by advanced modification technologies. Int J Nanomedicine 2018, 13, 3311-3327.

21. Correia, T. R.; Figueira, D. R.; de Sá, K. D.; Miguel, S. P.; Fradique, R. G.; Mendonça, A. G.; Correia, I. J., 3D Printed scaffolds with bactericidal activity aimed for bone tissue regeneration. International Journal of Biological Macromolecules 2016, 93, 1432-1445.

22. Vasilev, K.; Cook, J.; Griesser, H. J., Antibacterial surfaces for biomedical devices. Expert Review of Medical Devices 2009, 6 (5), 553-567.

23. Muwaffak, Z.; Goyanes, A.; Clark, V.; Basit, A. W.; Hilton, S. T.; Gaisford, S., Patient-specific 3D scanned and 3D printed antimicrobial polycaprolactone wound dressings. International Journal of Pharmaceutics 2017, 527 (1), 161-170.

24. Deng, L.; Deng, Y.; Xie, K., AgNPs-decorated 3D printed PEEK implant for infection control and bone repair. Colloids and Surfaces B: Biointerfaces 2017, 160, 483-492.

25. Zhang, Y.; Zhai, D.; Xu, M.; Yao, Q.; Zhu, H.; Chang, J.; Wu, C., 3D-printed bioceramic scaffolds with antibacterial and osteogenic activity. Biofabrication 2017, 9 (2), 025037.

26. Silver Nanoparticle Impregnated Poly ( $\varepsilon$-Caprolactone) Scaffolds: Optimization of Antimicrobial and Noncytotoxic Concentrations. Tissue Engineering Part A 2011, 17 (3-4), 439-449.

27. Kalakonda, P.; Aldhahri, M. A.; Abdel-wahab, M. S.; Tamayol, A.; Moghaddam, K. M.; Ben Rached, F.; Pain, A.; Khademhosseini, A.; Memic, A.; Chaieb, S., Microfibrous silver-coated polymeric scaffolds with tunable mechanical properties. RSC Advances 2017, 7 (55), 34331-34338.

28. Zhou, Y.; Thakurathi, M.; Quitevis, E. L.; Tan, G. Z., Electrospinning 3D Nanofiber Structure of Polycaprolactone Incorporated with Silver Nanoparticles. JOM 2019, 71 (3), 956-962.

29. Vu, T.-L.; Barés, J., Soft-grain compression: Beyond the jamming point. Physical Review $E$ 2019, 100 (4), 042907.

30. Vu, T. L.; Barés, J.; Mora, S.; Nezamabadi, S., Deformation Field in Diametrically Loaded Soft Cylinders. Experimental Mechanics 2019, 59 (4), 453-467.

31. Pastoriza-Santos, I.; Liz-Marzán, L. M., N,N-Dimethylformamide as a Reaction Medium for Metal Nanoparticle Synthesis. Advanced Functional Materials 2009, 19 (5), 679-688.

32. Park, J.; Lee, S. J.; Jo, H. H.; Lee, J. H.; Kim, W. D.; Lee, J. Y.; Park, S. A., Fabrication and characterization of 3D-printed bone-like $\beta$-tricalcium phosphate/polycaprolactone scaffolds for dental tissue engineering. Journal of Industrial and Engineering Chemistry 2017, 46, 175-181.

33. Murphy, C. M.; Haugh, M. G.; O'Brien, F. J., The effect of mean pore size on cell attachment, proliferation and migration in collagen-glycosaminoglycan scaffolds for bone tissue engineering. Biomaterials 2010, 31 (3), 461-466.

34. Elzein, T.; Nasser-Eddine, M.; Delaite, C.; Bistac, S.; Dumas, P., FTIR study of polycaprolactone chain organization at interfaces. Journal of Colloid and Interface Science 2004, 273 (2), 381-387.

35. López-Esparza, J.; Espinosa-Cristóbal, L. F.; Donohue-Cornejo, A.; Reyes-López, S. Y., Antimicrobial Activity of Silver Nanoparticles in Polycaprolactone Nanofibers against Gram-Positive and Gram-Negative Bacteria. Industrial \& Engineering Chemistry Research 2016, 55 (49), 1253212538.

36. Thomas, S.; Nair, S. K.; Jamal, E. M. A.; Al-Harthi, S. H.; Varma, M. R.; Anantharaman, M. R., Size-dependent surface plasmon resonance in silver silica nanocomposites. Nanotechnology 2008, 19 (7), 075710.

37. Ren, S.; Dong, L.; Zhang, X.; Lei, T.; Ehrenhauser, F.; Song, K.; Li, M.; Sun, X.; Wu, Q., Electrospun Nanofibers Made of Silver Nanoparticles, Cellulose Nanocrystals, and Polyacrylonitrile as Substrates for Surface-Enhanced Raman Scattering. Materials 2017, 10 (1), 68.

38. Pastoriza-Santos, I.; Liz-Marzán, L. M., Formation and Stabilization of Silver Nanoparticles through Reduction by N,N-Dimethylformamide. Langmuir 1999, 15 (4), 948-951. 
39. Lv, Q.; Wu, D.; Xie, H.; Peng, S.; Chen, Y.; Xu, C., Crystallization of poly(e-caprolactone) in its immiscible blend with polylactide: insight into the role of annealing histories. RSC Advances 2016, 6 (44), 37721-37730.

40. Eshraghi, S.; Das, S., Mechanical and microstructural properties of polycaprolactone scaffolds with one-dimensional, two-dimensional, and three-dimensional orthogonally oriented porous architectures produced by selective laser sintering. Acta Biomaterialia 2010, 6 (7), 24672476.

41. Ahn, S. H.; Kim, S. H.; Kim, B. C.; Shim, K. B.; Cho, B. G., Mechanical properties of silica nanoparticle reinforced poly(ethylene 2, 6-naphthalate). Macromolecular Research 2004,12 (3), 293-302.

42. Guerrica-Echevarría, G.; Eguiazábal, J. I.; Nazábal, J., Influence of molding conditions and talc content on the properties of polypropylene composites. European Polymer Journal 1998, 34 (8), 1213-1219.

43. The Design of Scaffolds for Use in Tissue Engineering. Part I. Traditional Factors. Tissue Engineering 2001, 7 (6), 679-689.

44. Khan, I.; Nagarjuna, R.; Dutta, J. R.; Ganesan, R., Enzyme-Embedded Degradation of Poly( $(\varepsilon-$ caprolactone) using Lipase-Derived from Probiotic Lactobacillus plantarum. ACS Omega 2019, 4 (2), 2844-2852.

45. Neumann, R.; Neunzehn, J.; Hinueber, C.; Flath, T.; Schulze, F. P.; Wiesmann, H. P., 3Dprinted poly- $\varepsilon$-caprolactone-CaCO3-biocomposite-scaffolds for hard tissue regeneration. Express Polym. Lett. 2019, 13, 2-17.

47. Hadrup, N.; Sharma, A. K.; Loeschner, K., Toxicity of silver ions, metallic silver, and silver nanoparticle materials after in vivo dermal and mucosal surface exposure: A review. Regulatory Toxicology and Pharmacology 2018, 98, 257-267.

48. Erick Pazos-Ortiz, J. H. R.-R., Efrén Amador Hinojos-Márquez, Juan López-Esparza, Alejandro Donohué-Cornejo, Juan Carlos Cuevas-González, León Francisco Espinosa-Cristóbal , and Simón Yobanny Reyes-López, Dose-Dependent Antimicrobial Activity of Silver Nanoparticles on Polycaprolactone Fibers against Gram-Positive and Gram-Negative Bacteria. Journal of nanomaterials 2017, 2017, 1-8. 